\title{
Numerical Analysis of the End-Suspended Pile and the Rock-Socketed Pile Bearing Capacity of a Soil-Rock Composite Foundation Pit
}

\author{
Xiaobo Xing, ${ }^{1}$ Xiangyang Li $\mathbb{D}^{,},{ }^{2}$ Wei Li, ${ }^{1}$ Tu Lu, ${ }^{3}$ Xiaofeng Duan, ${ }^{4}$ and Qing Jin $\mathbb{D}^{2}$ \\ ${ }^{1}$ Shandong Hi-Speed Qingdao Construction Management Group Co., Ltd., Jinan, Shandong 266000, China \\ ${ }^{2}$ School of Civil Engineering, Shandong University, Jinan, Shandong 250000, China \\ ${ }^{3}$ China Construction Infrastructure Corp., Ltd., Beijing, 100029, China \\ ${ }^{4}$ Shandong Luqiao Construction Co., Ltd., Jinan, Shandong, 250000, China \\ Correspondence should be addressed to Qing Jin; 1098470773@qq.com
}

Received 13 October 2021; Accepted 18 January 2022; Published 25 February 2022

Academic Editor: Guojun Wu

Copyright (C) 2022 Xiaobo Xing et al. This is an open access article distributed under the Creative Commons Attribution License, which permits unrestricted use, distribution, and reproduction in any medium, provided the original work is properly cited.

The bearing capacity of the rock-socketed part of the end-suspended pile and rock-socketed pile was investigated. Numerical models have been partially established with half of the pile and half of the pile space to simplify the model and reduce the number of elements. The strain-softening model was adopted for the rock mass, and the Coulomb friction model was used to simulate the friction between the pile and the soil. Subsequently, the stress deformation and bearing capacity were obtained in the numerical simulation analysis. Finally, the effects of the different support structures, rock-socketed depth, diameter, spacing, and rock shoulder width on piles were analyzed. The numerical results show that both the ultimate bearing capacity and the antideformation capacity of the end-suspended pile are lower than those of the rock-socketed pile. The bearing capacity of both the end-suspended pile and rock-socketed pile increases with an increase in rock-socketed depth, diameter, and spacing. In addition, the performance of the end-suspended pile is also positively correlated with the rock shoulder width.

\section{Introduction}

Many scholars have studied soil foundation pit excavation and support and the related technologies; the application of these concepts in engineering is quite mature. Yanran et al. [1] studied the load-settlement characteristics of rocksocketed piles using a finite element method and analyzed the single pile bearing capacity and settlement of rocksocketed piles under vertical load. Liu and Zhou [2] analyzed a typical example of deep excavation engineering supported by rock-socketed piles with the entire embedded portion in rock to investigate the behavior of rock-socketed retaining piles. Lan [3] analyzed the rate of the length and diameter, the characteristics of overburdened soil, the features of the rock-socketed tip rock, and the techniques for pile construction and found that not all rock-socketed piles are endbearing piles. Zhao et al. [4] explored the relationship between the socketed depth and presented the influencing parameters and the minimum depth analytical solution by hydrostatic equilibrium. Kulkarni and Dewaikar [5] studied the effect of rock mass discontinuities by considering the rock quality designation. Dai et al. [6] presented the results of tests on piles socketed in a weak, artificial rock made of sand, cement, gypsum powder, and water and compared the test results with estimation methods in which the roughness of the pile-rock interface is modeled explicitly by assuming sinusoidal undulations along with the interface. Prakash and Muthukkumaran [7] studied the behavior of a rock-socketed pile under static lateral load in a soil-rock layered profile system by conducting a series of experimental programs on the model pile.

Nonetheless, studies on the soil-rock excavation deformation characteristics of the formation and design of supporting structures are rare. Currently, most of the soil- 
rock combinations of foundation pit support are referenced to a soil foundation pit. However, the deformation characteristics of a soil-rock combination foundation pit and general soil foundation pit are quite different. The design of soil-rock combination foundation pit supporting structures usually relies on local engineering experience. It is easy to over- or underestimate the strength of the rock, which leads to a radical or conservative design. Hong-jun et al. [8] studied the design methods, stability, depth of the pile body, axial stress of the anchor, and width of the reserved rock shoulder. Yuan et al. [9] simulated the foundation pit excavation of an end-suspended pile of pile-anchor-insert systems and compared it with actual monitoring data. Bai et al. [10] studied the deformation and dynamic responses of end-suspended piles for foundation pits in combined soilrock foundation pits under gantry crane moving loads. Yang et al. [11] evaluated different situations of anchor inclination, rock shoulder width, and embedded depth of the end-suspended pile and found that increased rock shoulder width or embedded depth can effectively control the stability and deformation of deep foundation pits. Mingzhu et al. [12] studied the end-suspended pile supporting structure applied in the soil-rock mixed stratum common in mountainous and hilly areas using unified strength theory and the revised Hoek-Brown strength criterion. Lei et al. [13] explored the deformation and internal force responses of end-suspended piles and obtained the effects of pile diameter, embedded depth, and rock-socketed depth on the horizontal displacement and bending moment distributions along the pile shaft. Xu et al. [14] discussed the influences of the socketed rock depth, the rock shoulder width, and the prestress of anchor cables on the deformations and mechanical properties of end-suspended piles and proposed optimization methods.

However, these studies did not compare the characteristics of end-suspended and rock-socketed piles or analyze the bearing capacity of the supporting structures in parameters such as rock-socketed depth, diameter, spacing of supporting piles, and rock shoulder width. In this study, we established numerical models of the end-suspended and rock-socketed piles. The effects of the rock-socketed depth, diameter, spacing, and rock shoulder width on piles were analyzed.

\section{Numerical Simulation Analysis}

This study includes a numerical simulation of end-suspended and rock-socketed piles using the Midas GTS N, 3D finite element analysis software for geotechnical engineering. In the idealized model, the stress and strain of the pile and the rock mass below the excavation level are symmetrical, and the axes of symmetry are the centerline of the pile and the centerline of the spacing between two piles, respectively. Therefore, the model is partially established with half of the pile and half of the pile space, considering the simplification of the model and the reduction in the number of elements, as shown in Figure 1.

Here, the ultimate bearing capacity of the rock-socketed part must be loaded to the limit, and the strain-softening

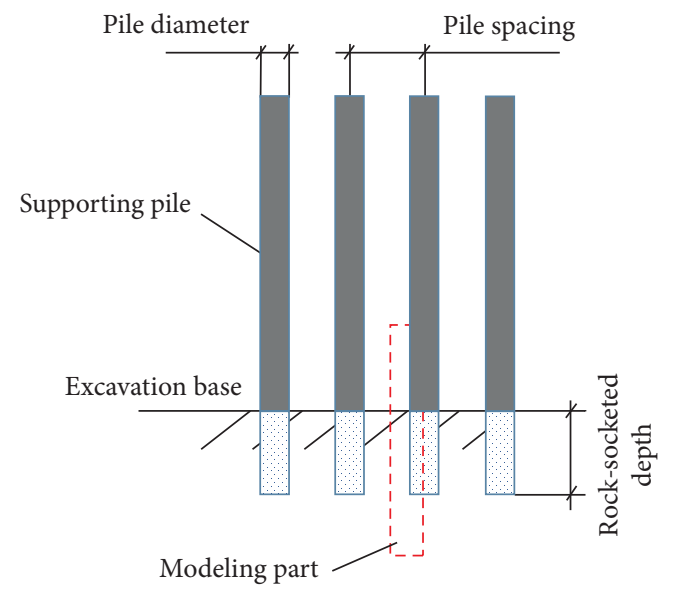

Figure 1: Modeling range of the 3D finite element model.

model can reflect the strain-softening process after rock damage. Therefore, the strain-softening model was adopted for the rock mass, and the model's stress-strain curve is shown in Figure 2. The supporting piles are not simplified as $1 \mathrm{D}$ line elements and plate elements but are considered as finite element models. The model needs to consider the spatial effect of the pile on the $3 \mathrm{D}$ simulation analysis because it is based on half of the pile and the pile spacing. The Coulomb friction model was used to simulate the friction between the pile and soil, and the strength of the contact was $70 \%$ of the rock strength. The lateral earth pressure of the soil layer above the excavation surface is simplified as the point load $P$ on the pile $[15,16]$.

\subsection{End-Suspended Pile}

2.1.1. Model Overview. The 3D model of the rock-socketed part of the end-suspended pile is shown in Figure 3. The model size was $20 \times 17 \times 0.75 \mathrm{~m}$, and there were $24,296 \mathrm{el}-$ ements. The boundary of the model defined its size. The bottom of the model constrains the degrees of freedom in the $X, Y$, and $Z$ directions; the front and back model faces constrain the degrees of freedom in the $Y$ direction, and the remaining two sides constrain the degrees of freedom in the $X$ direction. The model parameters are presented in Table 1 .

2.1.2. Stress Deformation Analysis. The rock shoulder horizontal displacement of the end-suspended pile in the ultimate limit state is shown in Figure 4. The horizontal displacement mainly occurs in the rock shoulder on the left side of the pile, and the horizontal displacement decreases approximately uniformly with a depth increase. The horizontal displacement of the right side of the pile and below the pile bottom is small, which illustrates that the effect of the pile on the rock shoulder is mainly concentrated above the rock-socketed depth.

The rock shoulder shear stress of the end-suspended pile in the ultimate limit state is shown in Figure 5(a). The shear stress on the rock shoulder slope is significant and gradually increases with an increase in the depth of the slope of the rock 


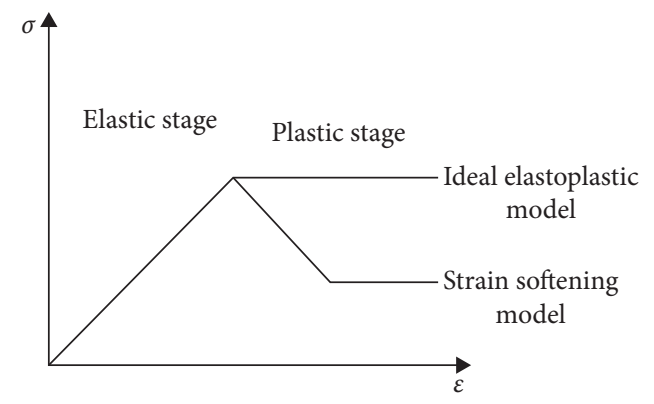

FIGURE 2: Strain-softening model stress-strain curve.

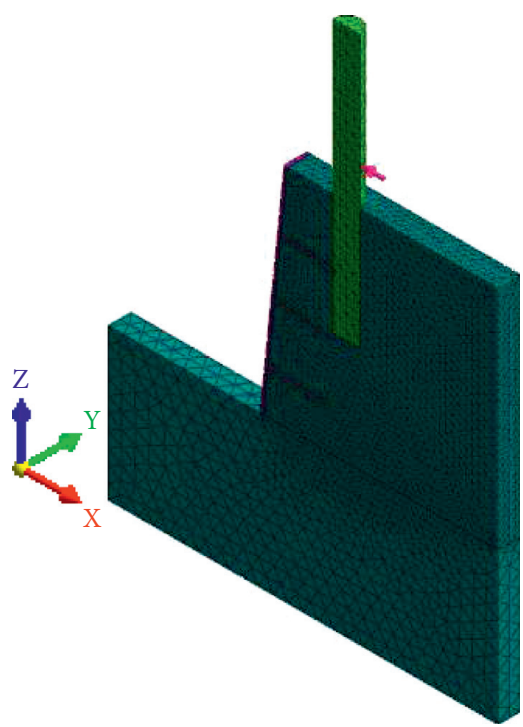

(a)

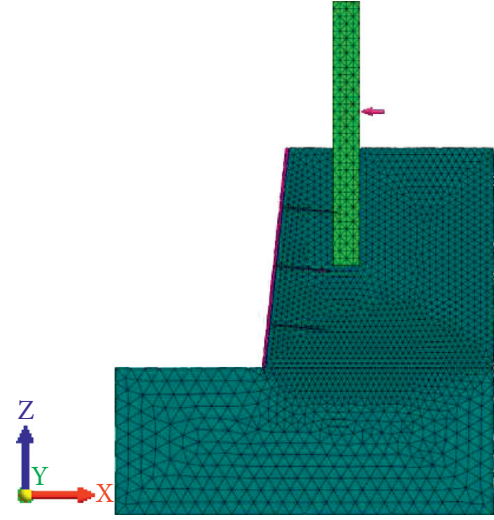

(b)

FIGURE 3: 3D model of the rock-socketed part of the end-suspended pile: (a) 3D model of the rock-socketed part of the end-suspended pile and (b) front view of the rock-socketed part model of the end-suspended pile.

TABLE 1: Rock structural parameters.

\begin{tabular}{lccccc}
\hline & $\begin{array}{c}\text { Elastic modulus, } E \\
(\mathrm{MPa})\end{array}$ & $\begin{array}{c}\text { Poisson's } \\
\text { ratio }\end{array}$ & $\begin{array}{c}\text { Internal friction angle, } \\
\varphi\left(^{\circ}\right)\end{array}$ & $\begin{array}{c}\text { Cohesion, } c \\
(\mathrm{KPa})\end{array}$ & $\begin{array}{c}\text { Residual internal friction } \\
\text { angle }\left(^{\circ}\right)\end{array}$ \\
\hline $\begin{array}{l}\text { Moderately weathered } \\
\text { limestone }\end{array}$ & $2.0 \times 10^{3}$ & 0.30 & 45 & 300 & 35 \\
Supporting pile & $3.0 \times 10^{4}$ & 0.2 & - & - & - \\
Shotcrete & $3.0 \times 10^{4}$ & 0.2 & 55 & 3,200 & - \\
Rock joint reinforcement & $2.0 \times 10^{5}$ & - & - & - & - \\
\hline
\end{tabular}

shoulder. The shear stress reaches a maximum at the pile bottom depth, and when the position gradually decreases to the bottom of the rock shoulder, the shear stress approaches 0 . The shear stress within the depth of the rock-socketed pile area was also significant, and there was an obvious oblique area with large shear stress in the upper portion.

Figure 5(b) shows the vertical stress of the rock shoulder under the ultimate limit state. The stress and deformation characteristics of the shoulder are close to those of the thick plate with fixed constraints on the bent side. The surface area of the shoulder is similar to the upper compression zone of the thick plate with bending, while the inner area near the pile side is the tension area. This phenomenon illustrates that the shear stress on the slope of the rock shoulder is larger because the shear stress in the Mohr-Coulomb failure criterion is related to the normal stress, which is larger on the compression side; therefore, the shear stress becomes relatively larger.

The plastic zone of the shoulder in the ultimate limit state is shown in Figure 6. The front side is the cross-section of the central position of the pile, and the reverse side is the crosssection of the central position of the pile spacing. The red part represents the plastic zone. The plastic zone is the same 


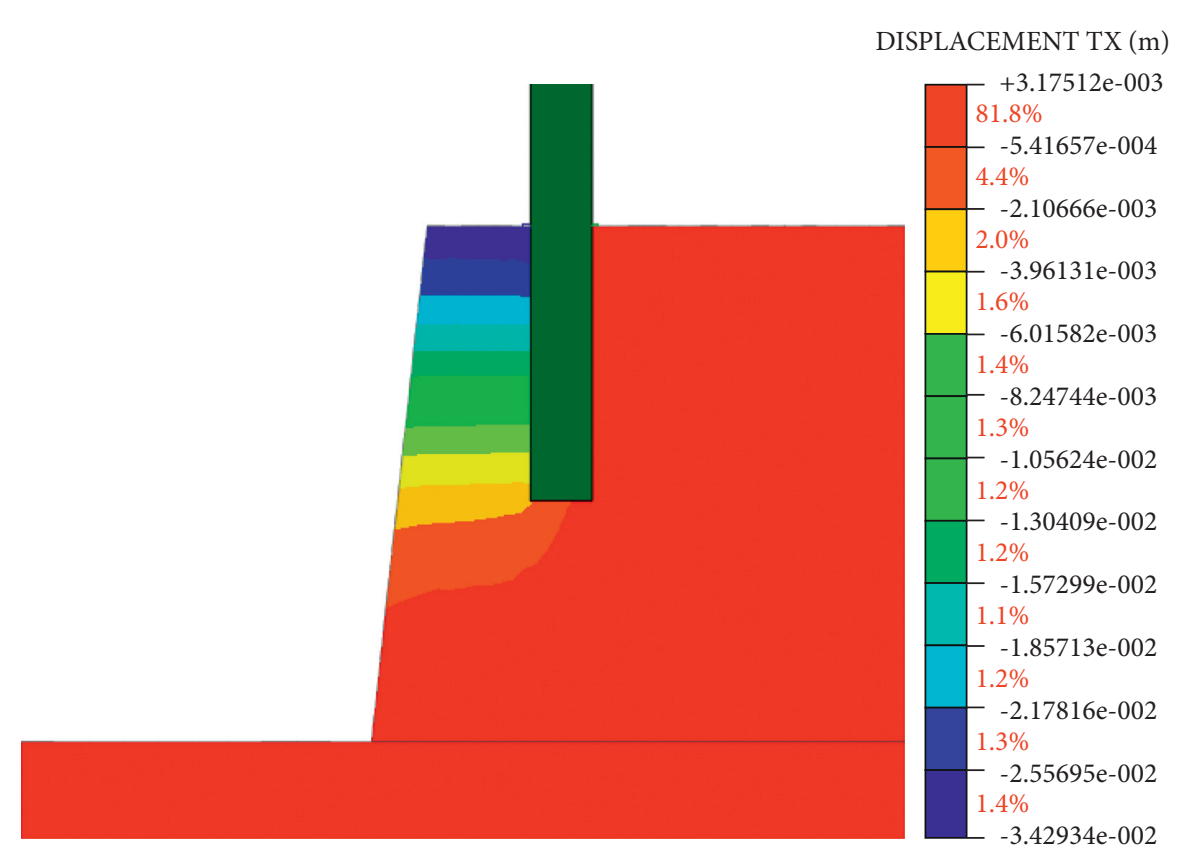

FIGURE 4: Nephogram of end-suspended pile horizontal displacement in the ultimate limit state.

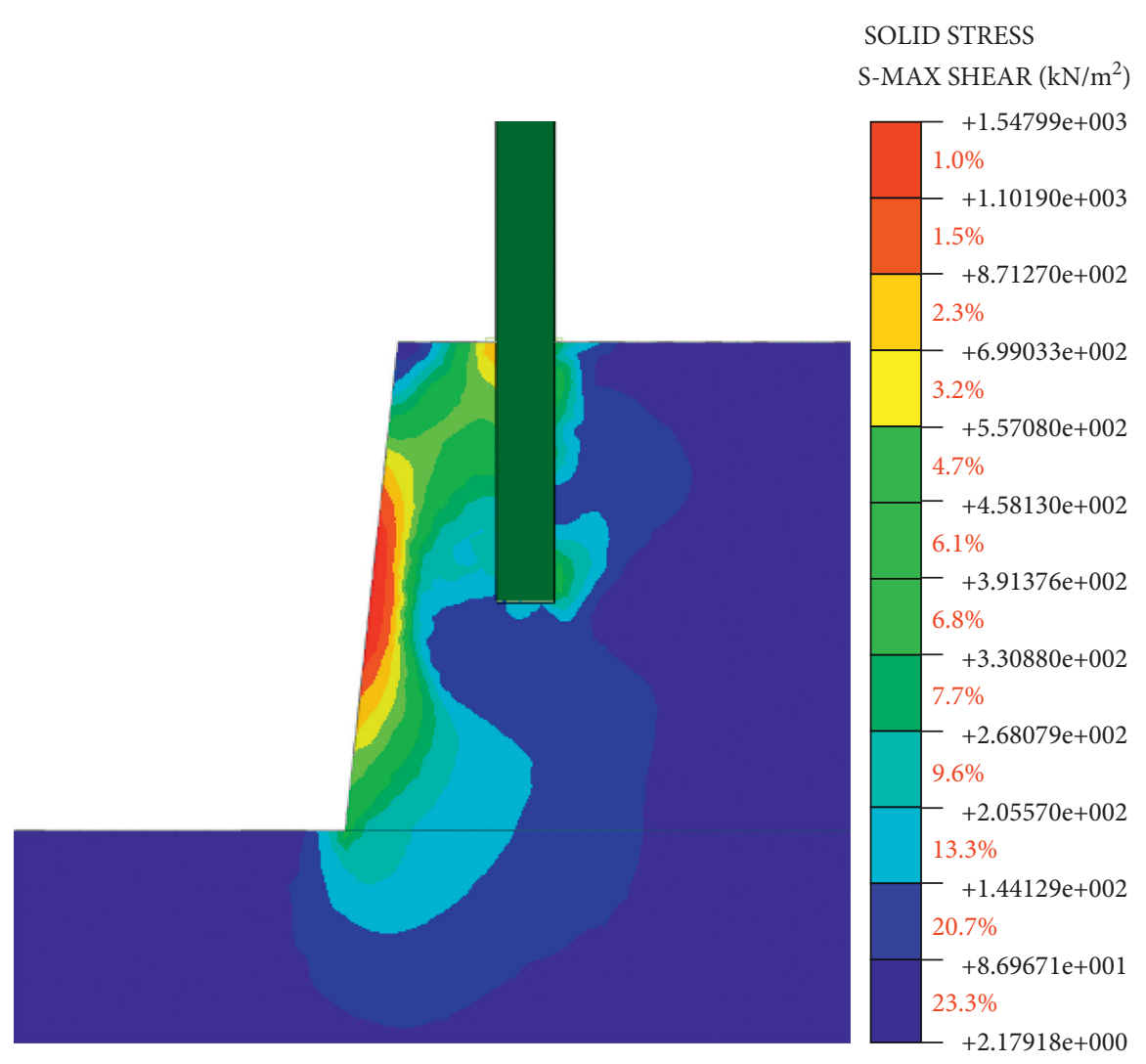

(a)

FIgURE 5: Continued. 


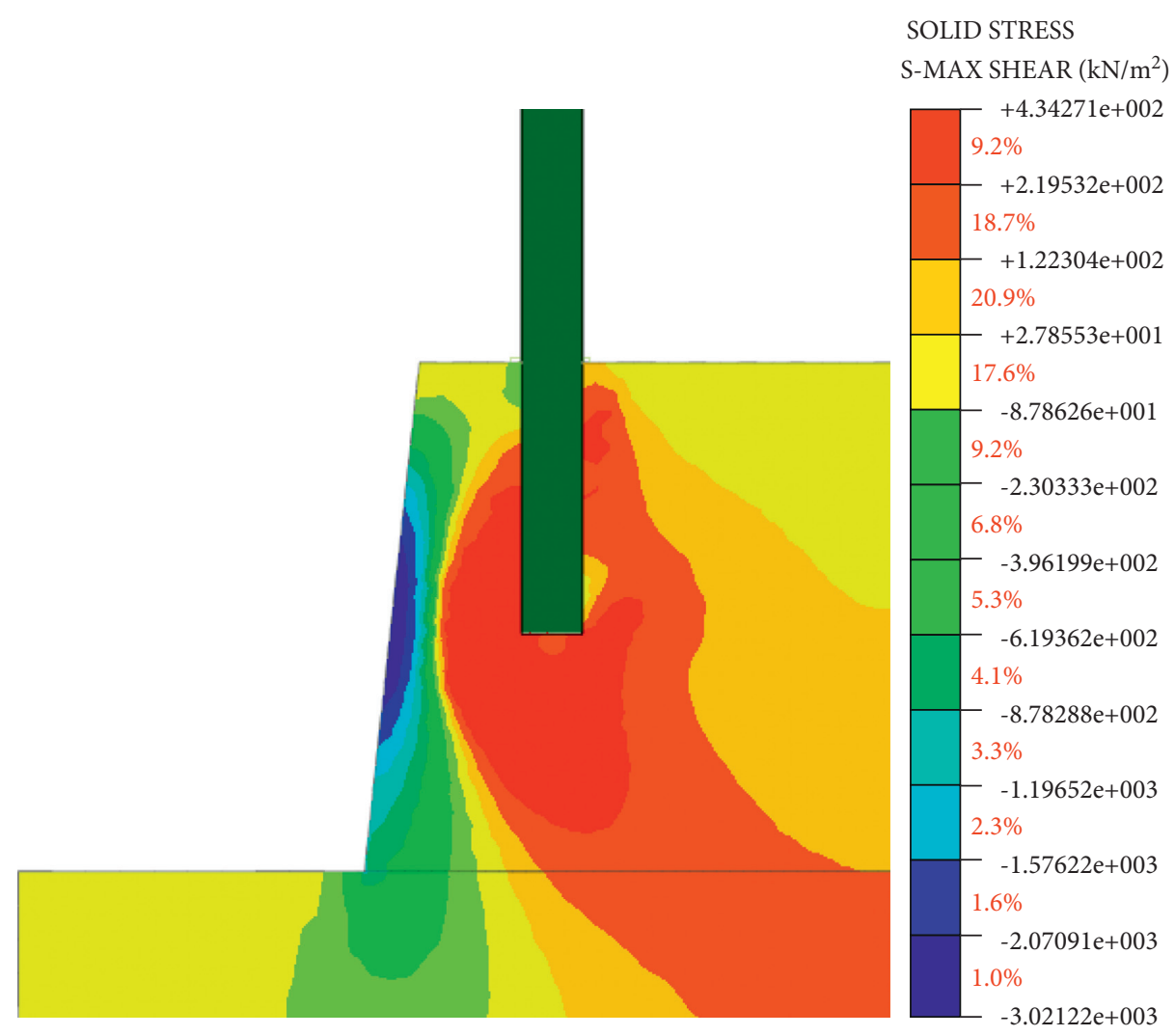

(b)

Figure 5: The stress nephogram of the end-suspended pile: (a) shear stress nephogram in the ultimate limit state and (b) normal stress nephogram in $Z$ direction in the ultimate limit state.

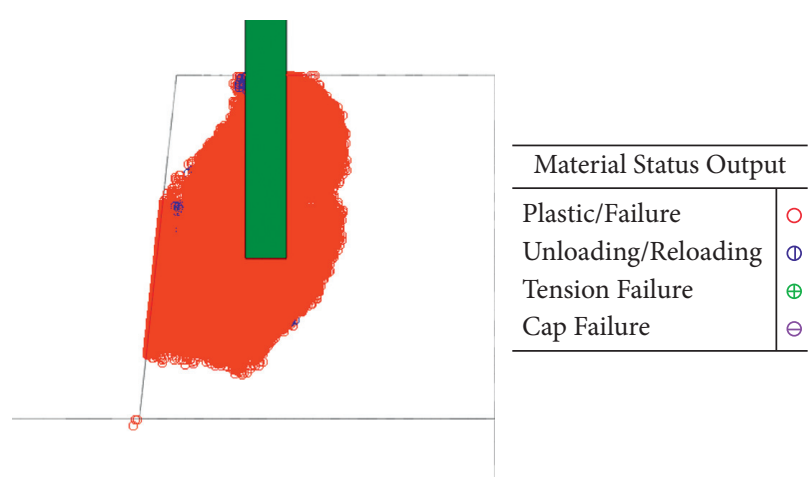

(a)

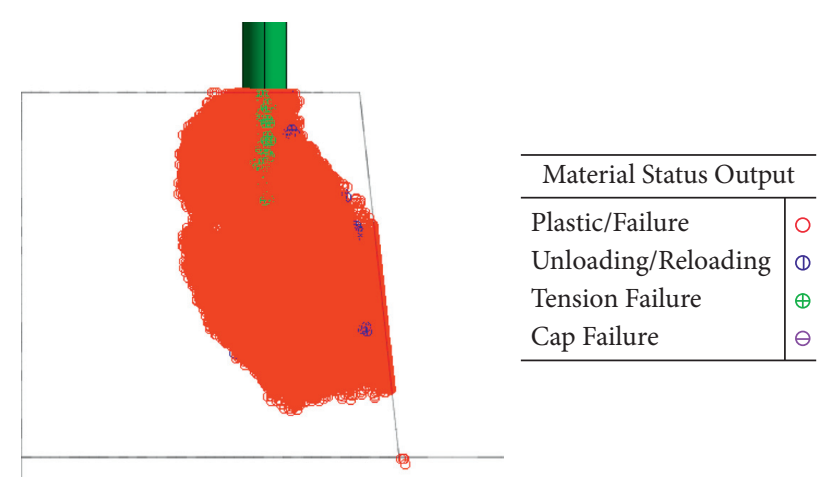

(b)

FIGURE 6: Plastic zone of the shoulder in the ultimate state: (a) front side and (b) reverse side.

as the area with large shear stress because the plastic state is dependent on the shear stress in the Mohr-Coulomb failure criterion. There is also a tensile failure zone (green) between the two piles (Figure $6(\mathrm{~b})$ ), which means that the forward horizontal displacement of the pile leads to a tensile failure zone between the two piles.
2.1.3. Bearing Capacity Analysis. In 2002, Gabr developed the $p-y$ hyperbolic function method based on weathered rock conditions by analyzing the finite element model and the results of laboratory and field horizontal load tests. The parameters are the foundation modulus $k$ and ultimate reaction force $P_{\max }$, and the function form is 


$$
\begin{aligned}
& p=\frac{y}{a+b y}, \\
& a=\frac{1}{k}, b=\frac{1}{p_{\text {max }}} .
\end{aligned}
$$

The numerical simulation results are fitted by equations (1) and (2), and the results are shown in Figure 7. There are three obvious sections in the $p-y$ curve: initial linear section, transition section, and terminal linear section. When the load is small, the $p-y$ curve is in the initial linear section, and the rock mass is in the elastic stage. The plastic zone of the rock shoulder is shown in Figure 8(a); the $p-y$ curve is approximately a straight line; and the load $p$ increases rapidly. With a load increase, the $p-y$ curve is in the transition section. Part of the rock mass around the pile enters the plastic section, as shown in Figure 8(b), and the range of the plastic zone gradually increases. Therefore, the tangent slope of the $p-y$ curve gradually decreases, which indicates that the antideformation capacity decreases because some rocks enter the plastic section. In the terminal linear section, most of the rock around the pile enters the plastic stage, as shown in Figure 8(c). At the end of the linear section, the $p-y$ curve approximates a gentle straight line or even a horizontal line. At this time, the antideformation capacity of the rock mass around the pile was reduced to a minimum. Therefore, according to Zhang et al. [15], the bearing capacity of a pile is generally considered to be the endpoint of the transition section.

\subsection{Rock-Socketed Pile}

2.2.1. Model Overview. The 3D model of the rock-socketed part of the rock-socketed pile is shown in Figure 9; the model dimensions are $20 \times 17 \times 0.75 \mathrm{~m}$, and there are 24,296 elements. The model size boundary of the model defines its size. The bottom of the model constrains the degrees of freedom in the $X, Y$, and $Z$ directions; the front and back faces of the model constrain only the degrees of freedom in the $Y$ direction, and the remaining two sides constrain only the degrees of freedom in the $X$ direction. The model parameters are presented in Table 2.

2.2.2. Stress Deformation Analysis. The horizontal displacement of the rock-socketed part in the ultimate limit state is shown in Figure 10. The horizontal displacement of the upper part is large, and the maximum value occurs on the surface of the rock. The horizontal displacement gradually decreases with increased depth. In addition, the direction of the horizontal displacement is opposite to the action direction of the force at the bottom, which indicates that the rock-socketed part of the pile rotates counterclockwise at a certain angle.

Figure 11 shows the shear stress of the rock shoulder in the ultimate limit state. The stress and deformation characteristics of the rock shoulder were similar to those of a thick plate with fixed constraints on the bending side. The horizontal displacement analysis indicated that the pile displacement rotated counterclockwise under the load action. Therefore, the top half of the pile compresses the rock mass on the left side of the pile, and the bottom half of the pile compresses the rock mass on the right side of the pile; therefore, the shear stress of these two parts is significant.

2.2.3. Bearing Capacity Analysis. Figure 12 shows the $p-y$ curve of the rock-socketed pile. The $p-y$ curve has three obvious sections: the initial linear section, the transition section, and the terminal linear section. The plastic zone changes are shown in Figure 13. The plastic zone is small in the initial linear section. With an increase in load $p$, the range of the plastic zone gradually expands; the tangent slope of the $p-y$ curve gradually decreases; and the antideformation capacity gradually decreases.

\section{Comparison and Analysis}

3.1. Effect of the Different Support Structures. The $p-y$ curves of the rock-socketed and end-suspended piles are shown in Figure 14. The bearing capacity of a rock-socketed pile is significantly greater than that of an end-suspended pile. The bearing capacity of the end-suspended pile is $591.3 \mathrm{kN}$, which is $79.7 \%$ less than that of the rock-socketed pile $(2,915.5 \mathrm{kN})$. The foundation modulus $k$ fitted by the end-suspended pile is also small, at $79.0 \mathrm{MPa}$, which is $64.0 \%$ less than that of a rocksocketed pile (219.3 MPa). On the $p-y$ curve, the slope of the initial linear rock-socketed pile was significantly greater than that of the suspended pile. This phenomenon indicates that both the ultimate bearing capacity and antideformation capacity of the end-suspended pile are less than those of the rock-socketed pile. The bearing capacity reduction coefficient is the reduction range of the end-suspended pile bearing capacity relative to that of the rock-socketed pile, and the foundation modulus reduction coefficient is also defined. The calculation formula is shown in equations (3) and (4) and shows that the bearing capacity reduction coefficient under the original design condition was 0.797 , and the foundation modulus reduction coefficient was 0.640 .

$$
\alpha=\frac{p_{1}-p_{2}}{p_{2}},
$$

where $\alpha$ is the bearing capacity reduction factor, $p_{1}$ is the bearing capacity of the end-suspended pile, and $p_{2}$ is the bearing capacity of the rock-socketed pile.

$$
\beta=\frac{k_{1}-k_{2}}{k_{2}},
$$

where $\beta$ is the reduction coefficient of the foundation modulus, $k_{1}$ is the foundation modulus of the suspended pile, and $k_{2}$ is the modulus of the rock-socketed pile foundation.

\subsection{Effect of Support Structure Parameters}

3.2.1. Rock-Socketed Depth. In this study, five working conditions with different rock-socketed depths were established to compare the ultimate bearing capacities of the 


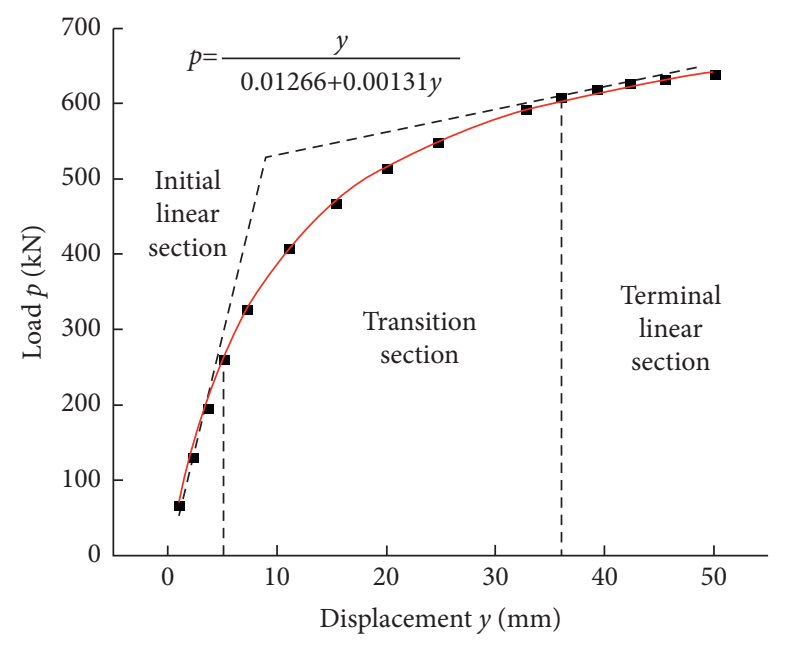

FIGURE 7: $p-y$ curve of the end-suspended pile.

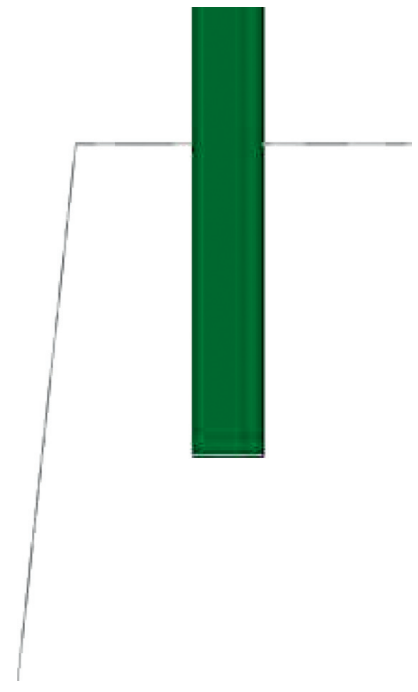

(a)

\begin{tabular}{l|c}
\hline \multicolumn{1}{c|}{ Material Status Output } \\
\hline Plastic/Failure & $\bigcirc$ \\
Unloading/Reloading & $\oplus$ \\
Tension Failure & $\oplus$ \\
Cap Failure & $\ominus$ \\
\hline
\end{tabular}

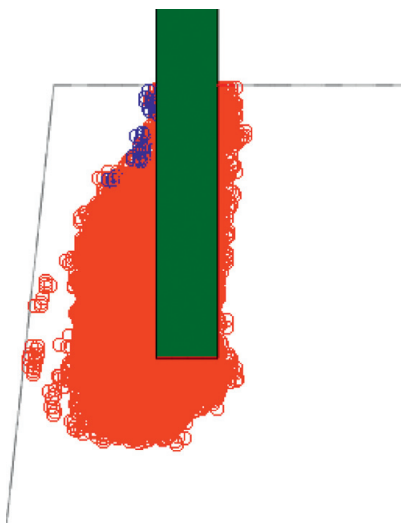

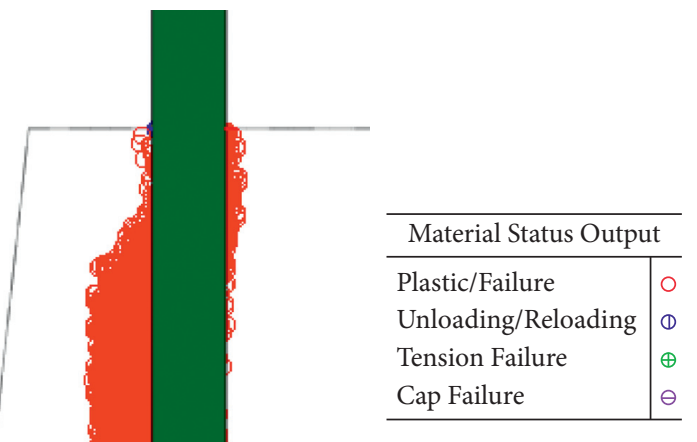

(b)

\begin{tabular}{l|c}
\hline \multicolumn{2}{c}{ Material Status Output } \\
\hline Plastic/Failure & $\odot$ \\
Unloading/Reloading & $\odot$ \\
Tension Failure & $\oplus$ \\
Cap Failure & $\ominus$ \\
\hline
\end{tabular}

(c)

FIgURE 8: Variation trend of plastic section: (a) initial linear section, (b) transition section, and (c) terminal linear section.

pile. The $p-y$ curve of the end-suspended pile under various working conditions and the fitting parameters of the curve are shown in Figure 15 and Table 3. The bearing capacity increases with increased rock-socketed depth, and the reduction coefficient of bearing capacity increases, which indicates that the difference between the bearing 


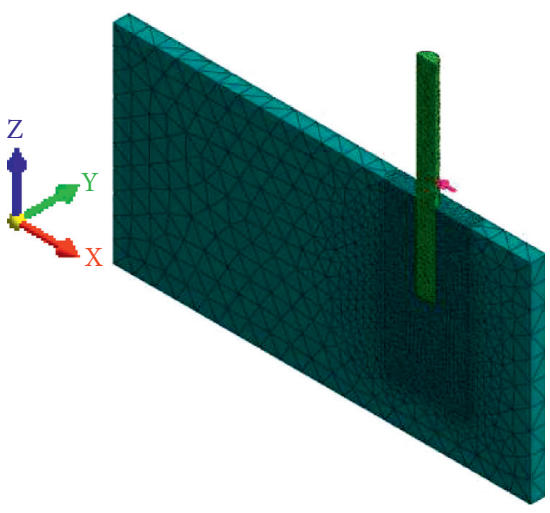

(a)

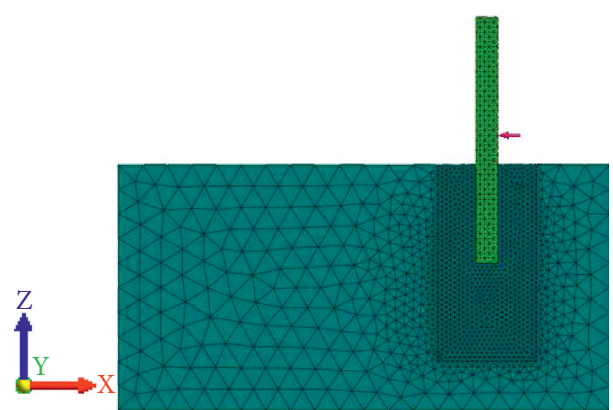

(b)

FIGURE 9: 3D model of the rock-socketed pile: (a) 3D model of the rock-socketed part of the rock-socketed pile and (b) front view of the rock-socketed part model of the rock-socketed pile.

TABLE 2: Rock structural parameters.

\begin{tabular}{lccccc}
\hline & $\begin{array}{c}\text { Elastic modulus, } E \\
(\mathrm{MPa})\end{array}$ & $\begin{array}{c}\text { Poisson's } \\
\text { ratio }\end{array}$ & $\begin{array}{c}\text { Internal friction angle, } \\
\varphi\left(^{\circ}\right)\end{array}$ & $\begin{array}{c}\text { Cohesion, } c \\
(\mathrm{kPa})\end{array}$ & $\begin{array}{c}\text { Residual internal friction } \\
\text { angle }\left(^{\circ}\right)\end{array}$ \\
\hline $\begin{array}{l}\text { Moderately weathered } \\
\text { limestone }\end{array}$ & $2.0 \times 10^{3}$ & 0.30 & 45 & 300 & 35 \\
Supporting pile & $3.0 \times 10^{4}$ & 0.2 & - & - & - \\
\hline
\end{tabular}

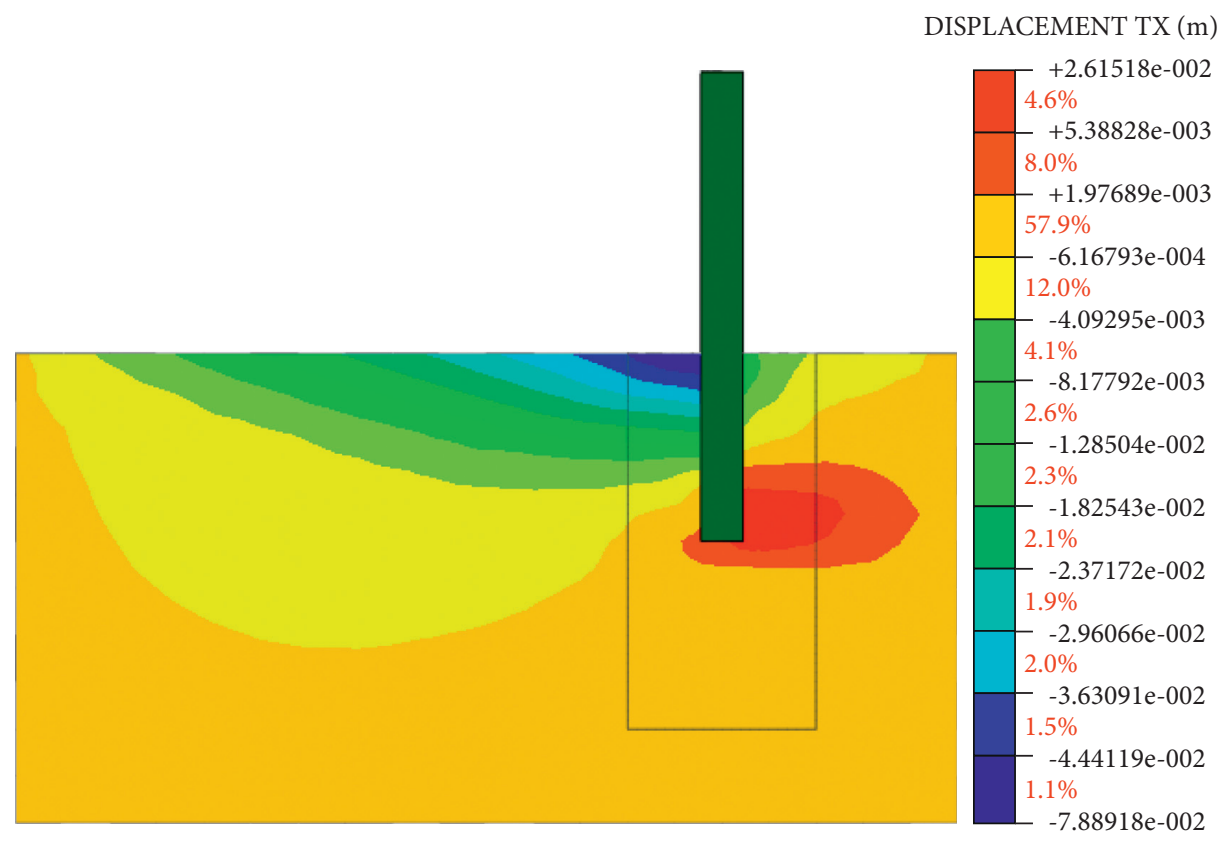

Figure 10: Nephogram of rock-socketed pile horizontal displacement in the ultimate limit state.

capacity of the end-suspended pile and rock-socketed pile increases gradually with the rock-socketed depth increase. When the rock-socketed depth is less than $3 \mathrm{~m}$, the foundation modulus $k$ increases rapidly. When the rocksocketed depth exceeds $3 \mathrm{~m}$, the growth rate slows, and the working condition of the $7 \mathrm{~m}$ rock-socketed depth is only 85.5 MPa.
The $p-y$ curve of the rock-socketed pile under various working conditions is shown in Figure 16, and the curvefitting parameters are listed in Table 4 . The range of the initial linear section gradually increases when the rocksocketed depth increases. The range of the initial linear section is short, and the curve enters the transition section when the working condition of rock-socketed depth is $1 \mathrm{~m}$. 


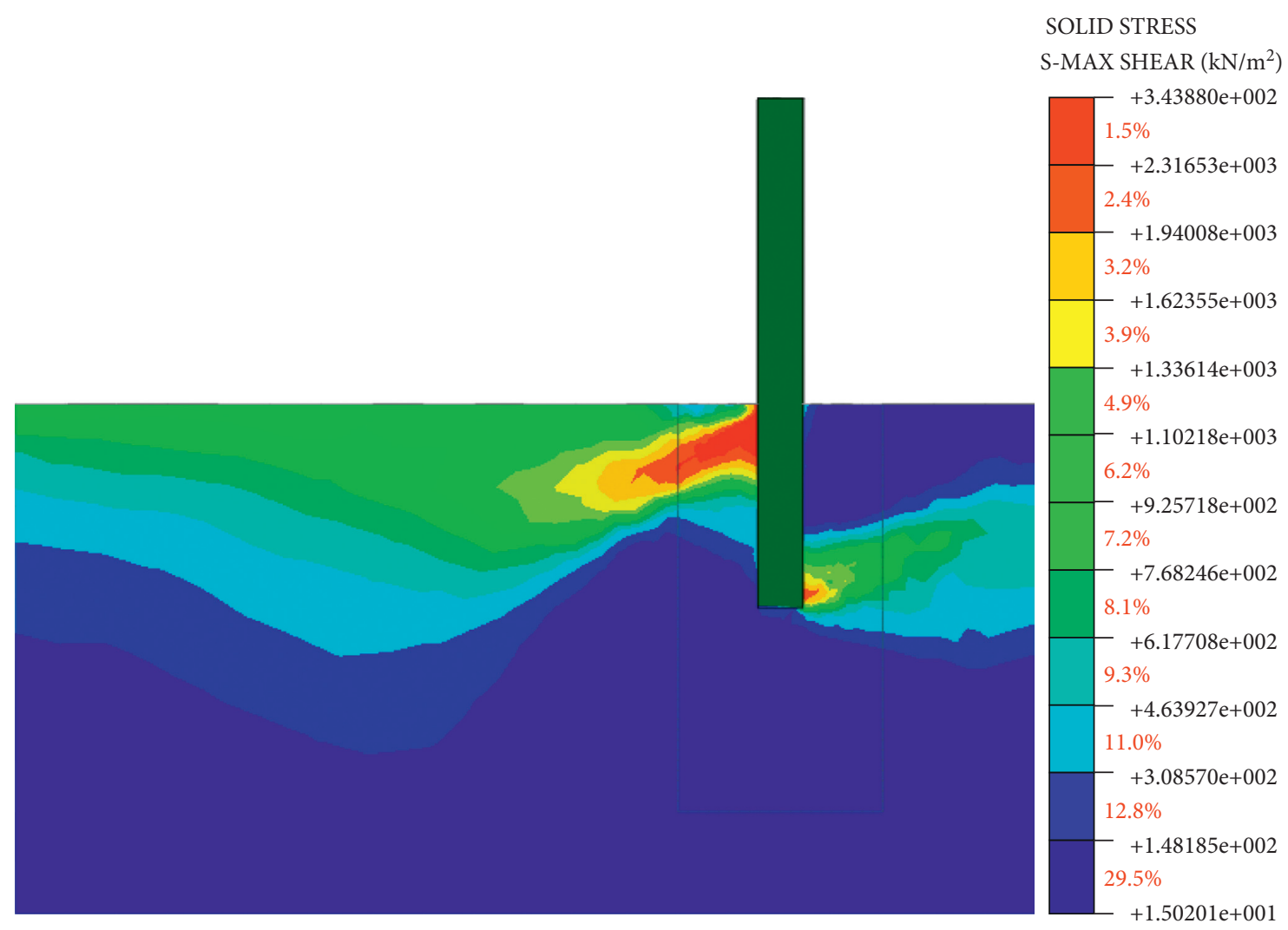

FIgURE 11: The shear stress nephogram of the rock-socketed pile.

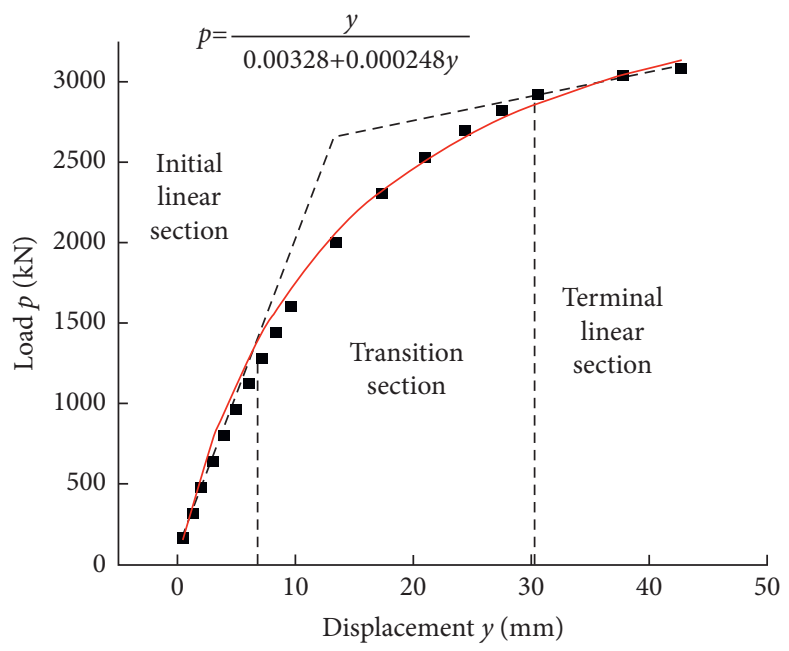

Figure 12: $p-y$ curve of the end-suspended pile.

However, when the working condition of the rock-socketed depth is $7 \mathrm{~m}$, the range of the initial linear section increases, and the entire $p-y$ curve exhibits an approximate linear growth trend. Similarly, the ultimate bearing capacity increases rapidly when the rock-socketed depth increases, whereas the foundation modulus $k$ increases slightly when the rock-socketed depth is greater than $3 \mathrm{~m}$. The ultimate bearing capacity increases when the rock-socketed depth is $1 \mathrm{~m}$, but the growth rate slows when the rock-socketed depth exceeds $3 \mathrm{~m}$, and the ultimate bearing capacity is only 85.5 $\mathrm{MPa}$ when the rock-socketed depth is $7 \mathrm{~m}$. The slope of the initial linear segment of the $p-y$ curve also increases significantly when the rock-socketed depth is $1-3 \mathrm{~m}$.

The bearing capacity of the end-suspended pile in each working condition was greater than $225.0 \mathrm{kN}$. However, the rock-socketed depth is $1 \mathrm{~m}$; the working condition bearing capacity is $280.3 \mathrm{kN}$; and when the rock-socketed depth is less than $3 \mathrm{~m}$, the foundation modulus $k$ increases rapidly. 


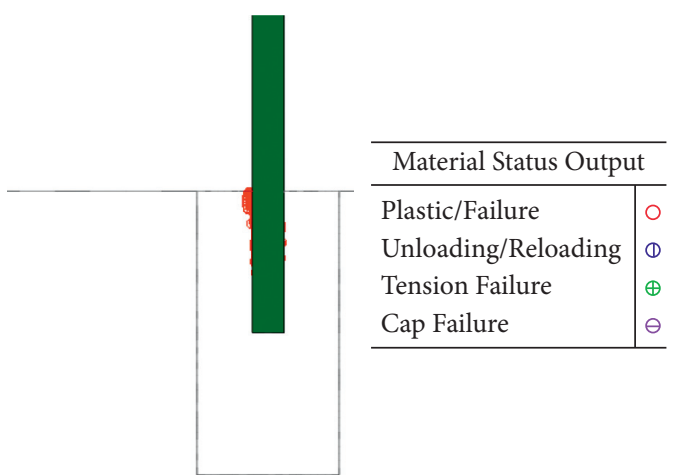

(a)

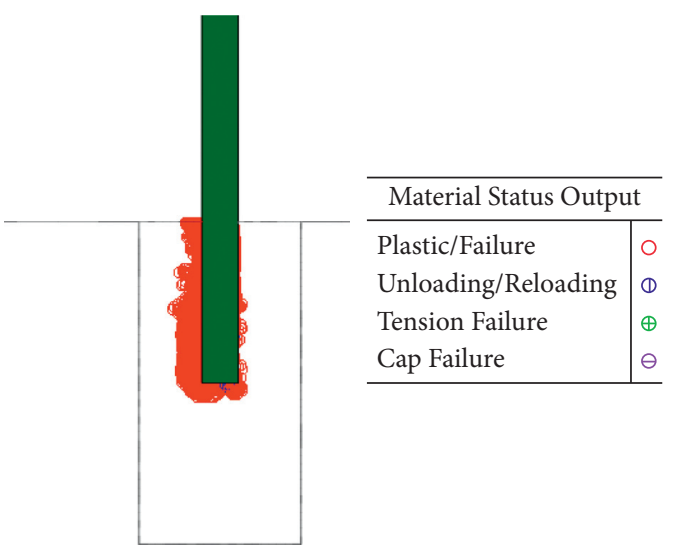

(b)

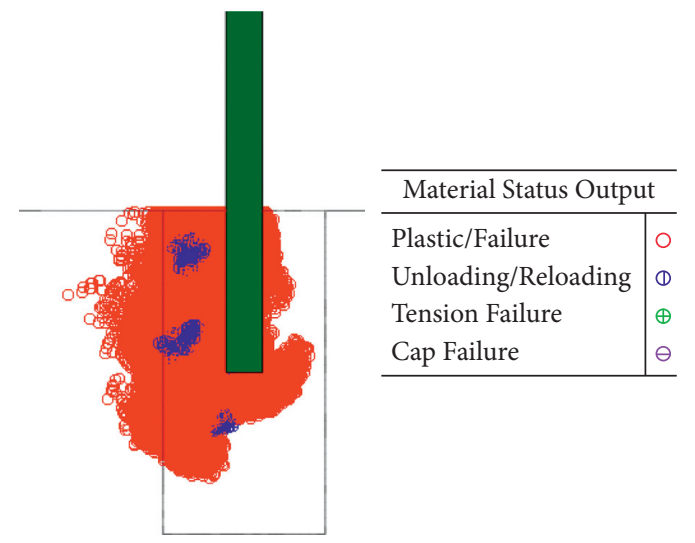

(c)

Figure 13: Variation trend of plastic section: (a) initial linear section, (b) transition section, and (c) terminal linear section.

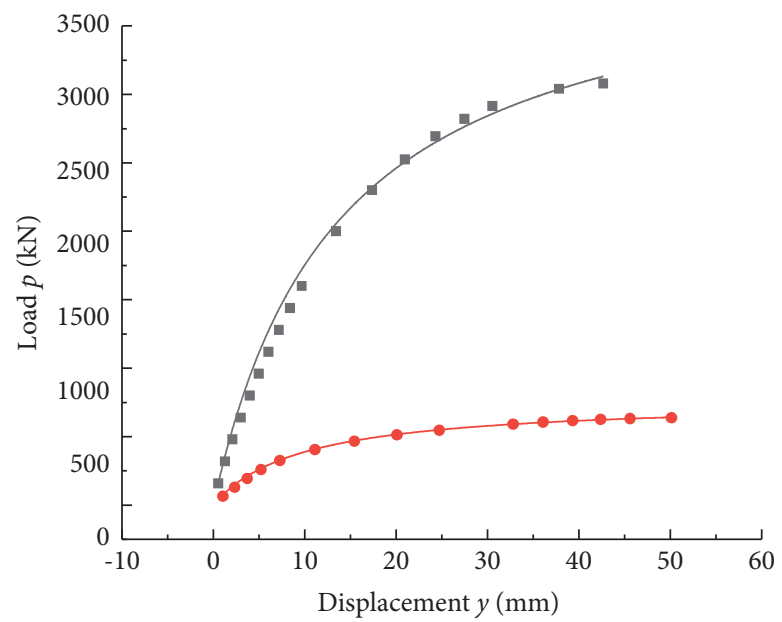

- Rock-socketed pile

- End-suspended pile

Figure 14: $p-y$ curves of the end-suspended and rock-socketed piles.

Considering pile deformation, the rock-socketed depth can be set as 3 to $4 \mathrm{~m}$, which means that the embedding ratio is $0.158-0.200$.
The maximum bearing capacity of the rock-socketed pile with a rock-socketed depth of $1 \mathrm{~m}$ was $497.9 \mathrm{kN}$. The bearing capacity of the rock-socketed pile at a depth of 2-7 m meets 


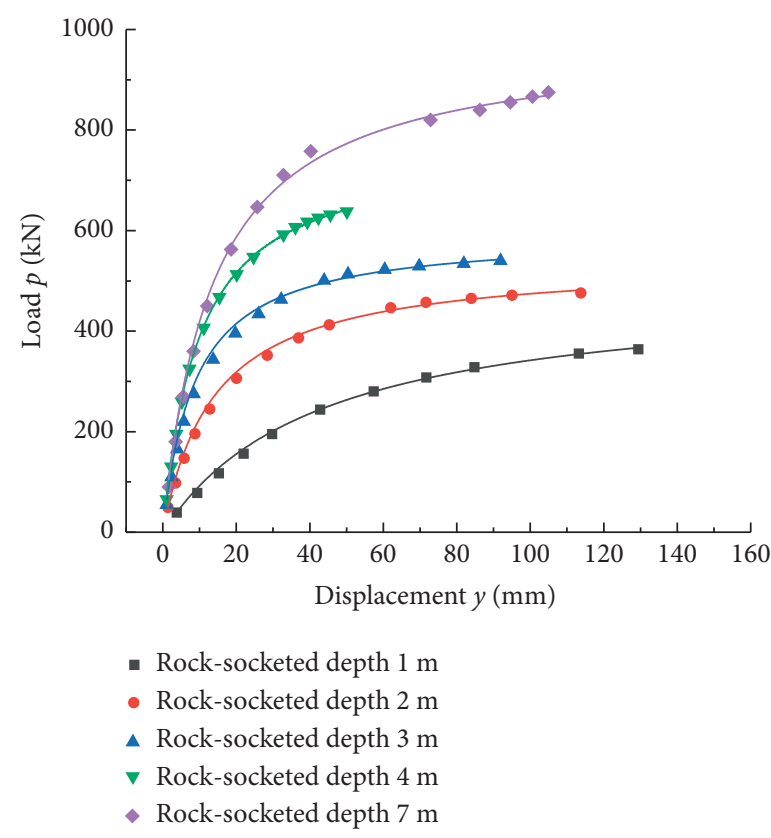

FIGURE 15: $p-y$ curve of the end-suspended pile under various working conditions.

TABLE 3: $p-y$ curve parameter of the end-suspended pile.

\begin{tabular}{|c|c|c|c|c|c|c|}
\hline Working condition & $\alpha$ & $\beta$ & $\begin{array}{l}\text { Bearing capacity } \\
(\mathrm{kN})\end{array}$ & $\begin{array}{c}k \\
(\mathrm{MPa})\end{array}$ & $\begin{array}{l}\text { Bearing capacity reduction } \\
\text { coefficient }\end{array}$ & $\begin{array}{l}\text { Foundation modulus reduction } \\
\text { coefficient }\end{array}$ \\
\hline $\begin{array}{l}\text { Rock-socketed depth } \\
1 \mathrm{~m}\end{array}$ & 0.0876 & 0.00205 & 280.3 & 11.4 & 0.427 & 0.934 \\
\hline $\begin{array}{l}\text { Rock-socketed depth } \\
2 \mathrm{~m}\end{array}$ & 0.0258 & 0.00185 & 414.2 & 38.8 & 0.653 & 0.826 \\
\hline $\begin{array}{l}\text { Rock-socketed depth } \\
3 \mathrm{~m}\end{array}$ & 0.0145 & 0.00168 & 496.6 & 69.0 & 0.738 & 0.754 \\
\hline $\begin{array}{l}\text { Rock-socketed depth } \\
4 \mathrm{~m}\end{array}$ & 0.0127 & 0.00131 & 591.3 & 78.7 & 0.797 & 0.742 \\
\hline $\begin{array}{l}\text { Rock-socketed depth } \\
7 \mathrm{~m}\end{array}$ & 0.0117 & 0.00102 & 757.6 & 85.5 & 0.787 & 0.711 \\
\hline
\end{tabular}

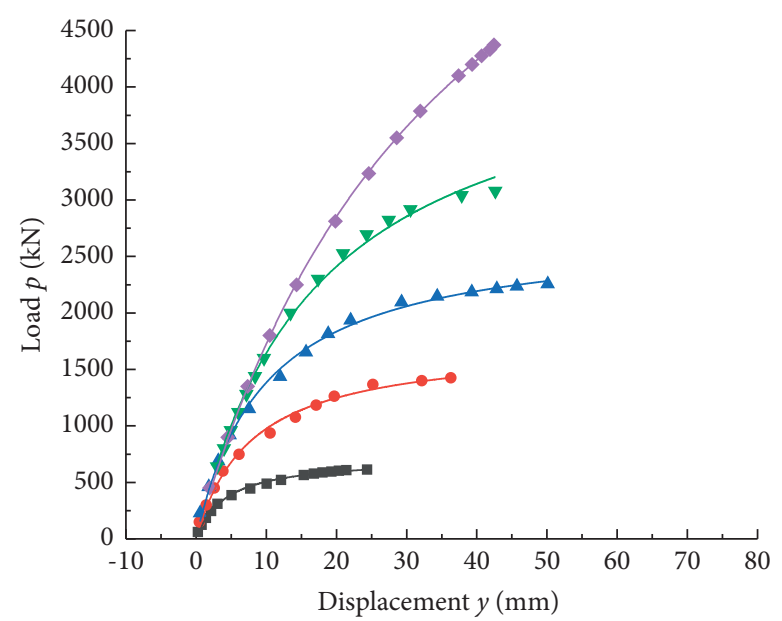

- Rock-socketed depth $1 \mathrm{~m}$

- Rock-socketed depth $2 \mathrm{~m}$

- Rock-socketed depth $3 \mathrm{~m}$

$\checkmark$ Rock-socketed depth $4 \mathrm{~m}$

- Rock-socketed depth $7 \mathrm{~m}$

FIGURE 16: $p-y$ curve of the rock-socketed pile under various working conditions. 
TABLE 4: $p-y$ curve parameter of the rock-socketed pile.

\begin{tabular}{|c|c|c|c|c|c|c|}
\hline Working condition & $\alpha$ & $\beta$ & $\begin{array}{l}\text { Bearing capacity } \\
(\mathrm{kN})\end{array}$ & $\begin{array}{c}k \\
(\mathrm{MPa})\end{array}$ & $\begin{array}{l}\text { Bearing capacity reduction } \\
\text { coefficient }\end{array}$ & $\begin{array}{c}\text { Foundation modulus reduction } \\
\text { coefficient }\end{array}$ \\
\hline $\begin{array}{l}\text { Rock-socketed depth } \\
1 \mathrm{~m}\end{array}$ & 0.00582 & 0.001390 & 489.2 & 171.8 & 0.00582 & 0.001390 \\
\hline $\begin{array}{l}\text { Rock-socketed depth } \\
2 \mathrm{~m}\end{array}$ & 0.00448 & 0.000577 & 1194.4 & 223.2 & 0.00448 & 0.000577 \\
\hline $\begin{array}{l}\text { Rock-socketed depth } \\
3 \mathrm{~m}\end{array}$ & 0.00356 & 0.000367 & 1898.8 & 280.9 & 0.00356 & 0.000367 \\
\hline $\begin{array}{l}\text { Rock-socketed depth } \\
4 \mathrm{~m}\end{array}$ & 0.00328 & 0.000248 & 2915.5 & 304.9 & 0.00328 & 0.000248 \\
\hline $\begin{array}{l}\text { Rock-socketed depth } \\
7 \mathrm{~m}\end{array}$ & 0.00338 & 0.000121 & 3562.6 & 295.9 & 0.00338 & 0.000121 \\
\hline
\end{tabular}

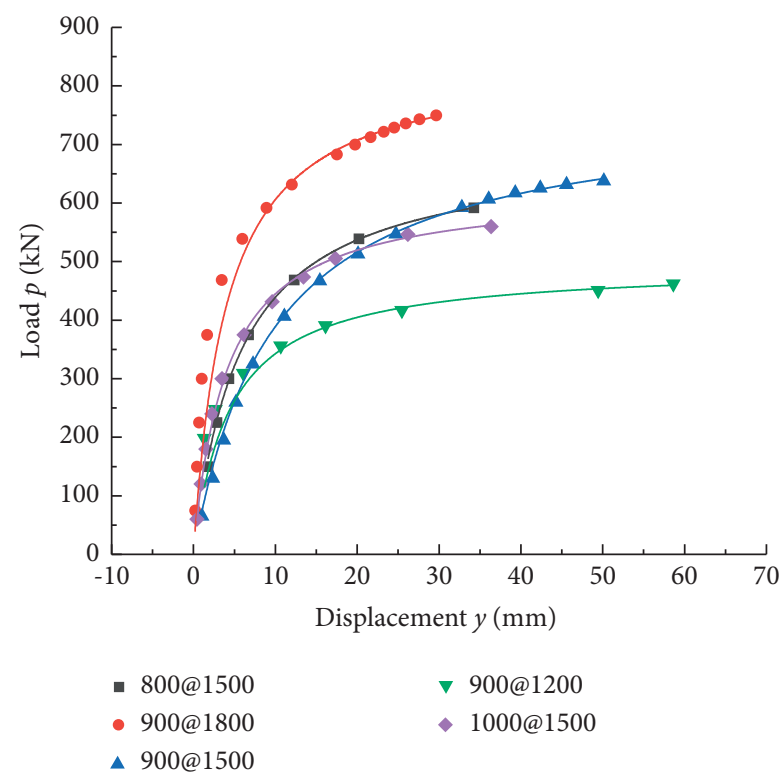

FIGURE 17: $p-y$ curve of the end-suspended pile under various working conditions.

the safety requirements. Considering pile deformation control, the foundation modulus is largest at the rocksocketed depth of $4 \mathrm{~m}$. Therefore, the rock-socketed depth can be set as 3 to $4 \mathrm{~m}$, which means that the embedding ratio is 0.167 to 0.210 .

3.2.2. Diameter and Spacing of Supporting Piles. Here, five working conditions with different support pile diameters and spacings were set. The $p-y$ curves of the end-suspended piles under various working conditions are shown in Figure 17, and the curve-fitting parameters are listed in Table 5. The $p-y$ curves of three of the working conditions are relatively similar, and there is little difference between the bearing capacity and foundation modulus of these conditions. This shows that pile spacing has a significant influence on bearing capacity: the greater the pile spacing, the greater the bearing capacity, while the pile diameter has little influence on the bearing capacity. The compression zone range was small when the pile spacing was small. The main stress zone of the shoulder was also the compression zone, as shown in Figure 18. Therefore, when the pile spacing is small, the ultimate bearing capacity and anti-deformation capacity of the shoulder decrease. The reduction coefficient of the bearing capacity varies slightly, and the reduction coefficient of the foundation modulus decreased gradually with increased pile spacing, from 0.806 (900@1,200) to 0.648 (900@1,800).

The $p$ - $y$ curves of rock-socketed piles under various working conditions are shown in Figure 19, and the curvefitting parameters are listed in Table 6. The pile spacing increased as the bearing capacity increased. The compression zone was reduced leading to bearing capacity reduction.

For both the rock-socketed and suspension piles, a change in the pile diameter has little influence on the bearing capacity and foundation modulus, but the pile spacing has a significant effect. Therefore, when the bearing capacity of rock-socketed parts is designed to be higher, increasing pile spacing is more effective than increasing pile diameter. However, it should also be considered that increasing pile spacing will lead to reduced equivalent bending stiffness and increased foundation pit deformation.

3.2.3. Rock Shoulder Width. Here, five working conditions with different rock shoulder widths were set. The $p-y$ curves of the end-suspended piles under various working 
TABLE 5: $p-y$ curve parameter of the end-suspended pile.

\begin{tabular}{lcccccc}
\hline $\begin{array}{l}\text { Working } \\
\text { condition }\end{array}$ & $\alpha$ & $\beta$ & $\begin{array}{c}\text { Bearing capacity } \\
(\mathrm{kN})\end{array}$ & $\begin{array}{c}k \\
(\mathrm{MPa})\end{array}$ & $\begin{array}{c}\text { Bearing capacity reduction } \\
\text { coefficient }\end{array}$ & $\begin{array}{c}\text { Foundation modulus reduction } \\
\text { coefficient }\end{array}$ \\
\hline $800 @ 1,500$ & 0.01288 & 0.00145 & 538.4 & 77.6 & 0.785 & 0.748 \\
$900 @ 1,800$ & 0.00748 & 0.00118 & 690.2 & 133.7 & 0.815 & 0.648 \\
$900 @ 1,500$ & 0.01265 & 0.00131 & 591.3 & 78.7 & 0.797 & 0.742 \\
$900 @ 1,200$ & 0.01395 & 0.00202 & 388.4 & 71.7 & 0.828 & 0.806 \\
$1,000 @ 1,500$ & 0.01245 & 0.00160 & 505.3 & 80.3 & 0.813 & 0.809 \\
\hline
\end{tabular}

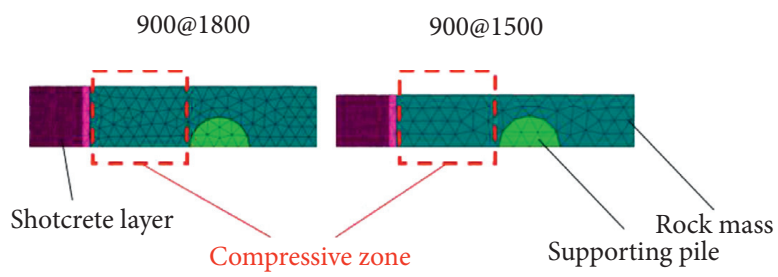

FIgURE 18: Diagram of partial compression area of the end-suspended pile.

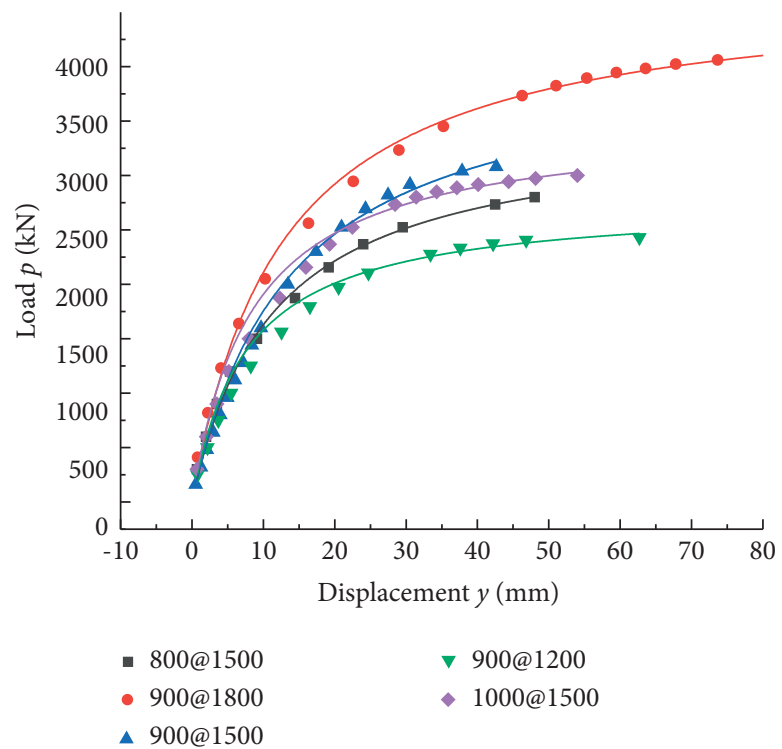

Figure 19: $p-y$ curve of the rock-socketed pile under various working conditions.

TABLE 6: $p-y$ curve parameter of the rock-socketed pile.

\begin{tabular}{lcccc}
\hline Working condition & A & $\beta$ & Bearing capacity $(\mathrm{kN})$ & $K(\mathrm{MPa})$ \\
\hline $800 @ 1,500$ & 0.00325 & 0.000289 & $2,505.0$ & 307.7 \\
$900 @ 1,800$ & 0.00263 & 0.000211 & $3,737.2$ & 380.2 \\
$900 @ 1,500$ & 0.00328 & 0.000248 & $2,915.5$ & 304.9 \\
$900 @ 1,200$ & 0.00271 & 0.000362 & $2,256.1$ & 369.0 \\
$1,000 @ 1,500$ & 0.00238 & 0.000286 & $2,709.1$ & 420.2 \\
\hline
\end{tabular}

conditions are shown in Figure 20, and the curve-fitting parameters are listed in Table 7 . When the rock shoulder width increases, the suspension pile bearing capacity increases. The minimum reduction coefficient of the bearing capacity indicates that even if the reserved shoulder width is $3 \mathrm{~m}$, there is still a significant gap between the bearing capacity of the end-suspended and rock-socketed piles. The modulus of the foundation also increases with increased shoulder width. The minimum bearing capacity is $359.7 \mathrm{kN}$ with a shoulder width of $0.5 \mathrm{~m}$. However, the foundation modulus is small with a shoulder width of $0.5 \mathrm{~m}$, so it is reasonable to design the shoulder width as $1.0-1.5 \mathrm{~m}$. 


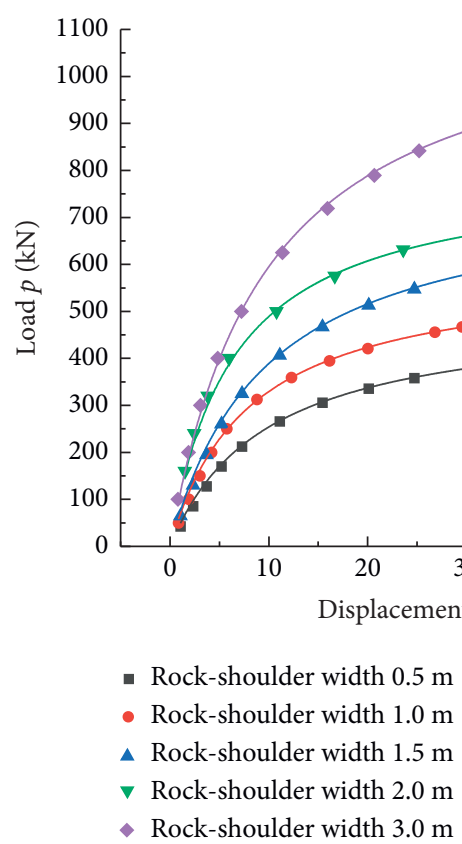

FIgURe 20: $p-y$ curve of the end-suspended pile under various working conditions.

TABLe 7: $p-y$ curve parameter of the end-suspended pile.

\begin{tabular}{|c|c|c|c|c|c|c|}
\hline Working condition & $\alpha$ & B & $\begin{array}{l}\text { Bearing capacity } \\
(\mathrm{kN})\end{array}$ & $\begin{array}{c}k \\
(\mathrm{MPa}) \\
\end{array}$ & $\begin{array}{l}\text { Bearing capacity reduction } \\
\text { coefficient }\end{array}$ & $\begin{array}{c}\text { Foundation modulus reduction } \\
\text { coefficient }\end{array}$ \\
\hline $\begin{array}{l}\text { Rock shoulder width } \\
0.5 \mathrm{~m}\end{array}$ & 0.01943 & 0.001990 & 359.7 & 51.5 & 0.877 & 0.831 \\
\hline $\begin{array}{l}\text { Rock shoulder width } \\
1.0 \mathrm{~m}\end{array}$ & 0.01347 & 0.001690 & 456.0 & 74.2 & 0.844 & 0.757 \\
\hline $\begin{array}{l}\text { Rock shoulder width } \\
1.5 \mathrm{~m}\end{array}$ & 0.01266 & 0.001310 & 591.3 & 78.7 & 0.797 & 0.742 \\
\hline $\begin{array}{l}\text { Rock shoulder width } \\
2.0 \mathrm{~m}\end{array}$ & 0.00795 & 0.001250 & 630.1 & 125.8 & 0.784 & 0.587 \\
\hline $\begin{array}{l}\text { Rock shoulder width } \\
3.0 \mathrm{~m}\end{array}$ & 0.00824 & 0.000856 & 907.9 & 121.4 & 0.689 & 0.602 \\
\hline
\end{tabular}

\section{Conclusions}

Here, we analyze the ultimate bearing capacity of rocksocketed parts of the end-suspended and rock-socketed piles using 3D finite element numerical simulation and the influence of the rock-socketed depth, shoulder width, spacing, and diameter of the supporting pile on the ultimate bearing capacity of the rock-socketed part. The main conclusions are as follows:

(1) The effect of the end-suspended pile on the shoulder is concentrated in the area above the bottom of the rock-socketed pile. The shear stress of the shoulder slope increases gradually as the depth increases and reaches the maximum at the pile bottom. There are areas of shear stress concentration inside the shoulder. The shear stress zone of the rock-socketed pile is mainly distributed on the left side of the upper part and the right side of the lower part.

(2) The $p-y$ curves of the end-suspended and rocksocketed piles can be divided into three distinct sections: initial linear section, transition section, and terminal linear. The plastic zone range of the rocksocketed part increases when the load increases. At the end of the linear section, the $p-y$ curve approximates a gentle straight line or even a horizontal line. Currently, the antideformation capacity of rock around the pile almost drops to the minimum.

(3) The ultimate bearing and antideformation capacities of the rock-socketed part of the end-suspended pile are far less than those of the rock-socketed pile. The bearing capacity of the end-suspended pile is only $20.3 \%$ of that of the rock-socketed pile, and the modulus of the foundation is only $36 \%$.

(4) With the increased rock-socketed depth, the bearing capacity of the end-suspended and rock-socketed piles increases, and a rock-socketed depth greater than $3 \mathrm{~m}$ has little influence on the modulus of foundation. The range of the compression zone significantly influences the bearing capacity of the rock-socketed part, and the greater the pile spacing, 
the greater the bearing capacity, while the pile diameter has a little influence on the bearing capacity. With the increased shoulder width, the bearing capacity and foundation modulus of the suspension pile increase. There is still a significant difference between the bearing capacity of the end-suspended pile and the rock-socketed pile when the reserved shoulder width is $3 \mathrm{~m}$.

\section{Data Availability}

No data were used to support this study.

\section{Conflicts of Interest}

The authors declare that they have no conflicts of interest.

\section{References}

[1] W. Yanran and P. A. N. Jiajun, "Finite element analysis of vertical load-settlement characters of rock-socketed piles," Engineering Journal of Wuhan University. engineering edition, vol. 39, no. 5, pp. 46-52, 2006.

[2] X. L. Liu and H. Zhou, "Investigation on behavior of rocksocketed retaining piles for deep excavation," in Proceedings of the 8th International Conference on Fracture and Strength of Solids (FEOFS) 2010, pp. 825-830, Kuala Lumpur, MALAYSIA, January 2011.

[3] J. Lan, "Understanding on the characteristics of bearing capacity and the calculating mode of rock-socketed piles," Geotechnical Investigation \& Surveying, vol. 38, no. 12, pp. 22-26, 2010.

[4] M. Zhao, M. Feng, M. Liu, P. Yin, and C. Yang, "A method to calculate socketed depth of large diameter rock-socketed piles in soft rock ground," Advances in Science and Technology of Water Resources, vol. 35, no. 1, pp. 73-77, 2015.

[5] R. U. Kulkarni and D. M. Dewaikar, "An empirical approach to assess socket friction and point resistance of axially loaded rock-socketed piles of Mumbai region," International Journal of Geotechnical Engineering, vol. 11, no. 5, pp. 479-486, 2017.

[6] G. Dai, R. Salgado, and M. Zhu, "The effect of sidewall roughness on the shaft resistance of rock-socketed piles," Acta Geotechnica, vol. 12, no. 2, pp. 429-440, 2017.

[7] A. R. Prakash and K. Muthukkumaran, "Estimation of lateral capacity of rock socketed piles in layered soil-rock profile," International Journal of Geo-Engineering, vol. 12, no. 1, 2021.

[8] L. I. U. Hong-jun, L. I. Dong, S. U. N. Tao, and L. I. U. Xiao-Li, "Numerical analysis on design of dualistic foundation pit with end-suspended pile," Journal of Civil, Architectural \& Environmental Engineering, vol. 31, no. 5, pp. 43-48, 2009.

[9] H.-y. Yuan, M.-y. Zhang, and H.-1. Kou, "Effect of the stiffness of "end-suspended pile" for the foundation pit supporting based on plaxis 2d," Journal of Qingdao Technological University, vol. 34, no. 2, pp. 31-35, 2013.

[10] X.-y. Bai, M.-y. Zhang, and H.-y. Yuan, "Deformation analysis for the end-suspended piles in the combined soil-rock foundation pits under moving loadings," Rock and Soil Mechanics, vol. 36, no. 4, pp. 1167-1173, 2015.

[11] Z. Yang, S. Shi, Y. Ping, and Z. Jiang, "Stability analysis of deep foundation pit with end-suspended pile supporting structure based on limit equilibrium finite difference method," in Proceedings of the 6th International Conference on Intelligent
Systems Design and Engineering Applications (ISDEA), pp. 734-738, Guiyang, PEOPLES R CHINA, August 2015.

[12] L. Mingzhu, L. Shengli, and W. Shijie, "Theoretical analysis on soil pressure acting on end-suspended pile supporting structure to foundation pit in soil-rock mixed stratum," IOP Conference Series: Earth and Environmental Science, vol. 525, no. 1, pp. 012081-012088, 2020.

[13] G. Lei, P. Guo, F. Hua, X. Gong, and L. Luo, "Observed Performance and Fem-Based Parametric Analysis of a TopDown Deep Excavation in Soil-Rock Composite Stratum," Advances in Freeze-Thaw Geomechanical Behavior of Rock Mass in Cold Regions, vol. 2021, Article ID 6964940, 2021.

[14] Q. Xu, Z. Bao, T. Lu, H. Gao, and J. Song, "Numerical simulation and optimization design of end-suspended pile support for soil-rock composite foundation pit," Advances in Civil Engineering, vol. 2021, Article ID 5593639, 2021.

[15] K. Zhang, G. Li, W. Du, and L. Xia, "Study on lateral bearing capacity of rock-socketed piles based on numerical tests," Journal of Sichuan University Engineering Science Edition, vol. 48, no. 6, pp. 58-67, 2016.

[16] W. Jianhua, C. Jinjian, and K. E. Xue, "Characteristics of large diameter rock-socketed piles under lateral loads," Chinese Journal of Geotechnical Engineering, vol. 29, no. 8, pp. 11941198, 2007. 